\title{
Pilgrimage Tourism: A Study on Palani Temple, Tamil Nadu
}

\author{
C Aruljothi* and S Ramaswamy ${ }^{\dagger}$
}

\section{Abstract}

India is a large country with great traditions, culture, and civilization. India has 4000 years of fertile civilized life with planned cities, monumental temples, mosques and churches, palaces, sculptures, paintings and various artistic creations. These scenic beauties have made India one of the most famous tourist destinations in the world. The Tourism potential of any country mainly depends on its climate, scenery, historical monuments, arts, tradition, festivals and the society. If any place or area or spot possesses all these characters and potentials, we may call it as a tourist centre or pilgrim centre. Tamil Nadu, a southern State of India, is a land of charm with ancient traditions; the picturesque land of Tamil Nadu has towering temples with magnificent architecture and sculptures, art galleries and heterogeneous natural beauty, existing on the hills and mountains. Tamil Nadu is flooded with different cultural, spiritual and religious centres like Madurai, Rameswaram, Kanyakumari, Tanjavur, Kumbakonam, Trichy, Kancheepuram, Chidambaram, Tiruvannamalai and Palani. Religious institutions like temples in Tamil Nadu have been playing a multifaceted role in religious, social, economic and cultural life of the Tamil community. Moreover, temples are considered as producers, land owners, trustees,

* Research Scholar, Department of Economics, Gandhigram Rural Institute- Deemed University, Gandhigram-624 302, Tamil Nadu.

† Professor and Head, Department of Economics, Gandhigram Rural Institute-Deemed University, Gandhigram-624 302, Tamil Nadu; srsmother@gmail.com. 
employers, pilgrim centres and institutions. There are studies conducted in cultural and spiritual tourism centres, which focus on heritage, culture and the historical aspects. But studies that focus on economic aspects of such centres are scanty. With this background, the authors have made an attempt to study the memories and reminiscence of 150 Pilgrimage tourists, who visited Palani Temple; one of the Six abodes of Lord Muruga located in the Dindigul district of Tamil Nadu, with an objective of examining the social and economic characteristics of the pilgrimage tourists; and identify their major problems and suggest ways and means for promoting pilgrimage tourism in Palani. The Primary data has been collected through interview schedules. The interview schedule was pre-tested, modified and wellstructured, and was used for obtaining information and data from the cultural-spiritual tourists, who are visiting the Palani temple. Secondary data in connection with the Palani temple were also gathered from the office of the Commissioner, Palani temple. Further, the authors have collected data and information from 150 tourists who visited the Palani temple during June-July 2011. The tourists were purposively selected in different spots in and around the Palani temple. For the purpose of analyzing the data, simple tools like ratio, percentage and average were used.

Keywords: Pilgrimage tourism; Architecture; Reminiscence

\section{Introduction}

Tourism plays a pivotal role in the socio-economic and cultural development of any economy. It is identified as one of the world's largest smoke free industries and its annual growth rate has been 5.0 per cent over the past twenty years. Tourism services are supported by human beings, irrespective of their age and gender. Economic significance of tourism is realized in almost all service sectoral activities. The main economic impact of tourism includes its contribution to the government revenue, generation of foreign exchanges and creation of employment, along with the creation of new business opportunities, improvement in the standard of living 
in host economies, promotion of foreign investments and other invisible earnings.

\section{Tourism Potentials in Tamil Nadu}

Tamil Nadu is a State with several distinguished tourism genre; leisure, pilgrimage, heritage, adventure, cruise, rural, responsible, business, medical, eco, culture, education, sports and so on. It has rich culture and heritage, cerulean mountains, verdant vegetables, sandy beaches, mammoth monuments, eternal temples, fabulous wild life, scintillating sculptures and reverberating rural life. Tamil Nadu has excellent hill stations like Ooty, Kodaikannal, Yercaud, Yelagiri, Javvadhu hills, Kolli Hills, Siurmalai hills etc., and it has silvery cascades in Coutralam, Hogenakkal, Monkey falls, Thitumurthi malai, Akasa Gangai and Papanasam. It has excellent national park and wild life sanctuaries in Mudumalai, Kodiakarai, Kalakkad, Mundanthurai and Berijam.

It has Botanical gardens in Ooty, Kodaikannal and Coimbatore. It has UNESCO declared monuments like living Chola temples at Thanjavur, Darasuram and Gangaikondacholapuram; monuments at Mamallapuram and Nilgris heritage Train are adding colours to the Tamil Nadu tourism map. Tourists visit various tourism destinations in Tamil Nadu from or within Tamil Nadu, other states in India and other countries, irrespective of their colour, age, gender, creed, caste, religion, language and so on. Tamil Nadu possesses huge potentialities to meet the needs of the tourists and their aspirants. It attracts a number of foreign tourists and domestic tourists every year. 
Table 1: Tourist Arrivals and Share of Tamil Nadu in India Arrivals (2000-2008)

\begin{tabular}{|l|l|l|l|l|l|l|}
\hline \multirow{2}{*}{ Year } & \multicolumn{2}{|c|}{$\begin{array}{c}\text { India :Tourists } \\
\text { arrivals (in lakhs) }\end{array}$} & \multicolumn{2}{c|}{$\begin{array}{c}\text { Tamil Nadu : } \\
\text { Tourists arrivals (in } \\
\text { Lakhs) }\end{array}$} & $\begin{array}{l}\text { Per cent share of } \\
\text { Tamil Nadu in } \\
\text { India's tourists } \\
\text { arrivals }\end{array}$ \\
\cline { 2 - 7 } & $\begin{array}{l}\text { Foreign } \\
\text { Tourists }\end{array}$ & $\begin{array}{l}\text { Domestic } \\
\text { Tourists }\end{array}$ & $\begin{array}{l}\text { Foreign } \\
\text { Tourists }\end{array}$ & $\begin{array}{l}\text { Domestic } \\
\text { Tourists }\end{array}$ & $\begin{array}{l}\text { Foreign } \\
\text { Tourists }\end{array}$ & $\begin{array}{l}\text { Domestic } \\
\text { Tourists }\end{array}$ \\
\hline 2000 & 58.9 & 2201.1 & 7.9 & 229.8 & 13.41 & 10.44 \\
\hline 2001 & 54.4 & 2364.7 & 7.73 & 238.12 & 14.20 & 10.06 \\
\hline 2002 & 51.6 & 2696.0 & 8.05 & 246.61 & 15.60 & 9.14 \\
\hline 2003 & 67.1 & 3090.4 & 9.02 & 270.59 & 13.44 & 8.75 \\
\hline 2004 & 83.6 & 3662.7 & 10.58 & 300.77 & 12.65 & 8.21 \\
\hline 2005 & 99.5 & 3919.5 & 11.79 & 323.39 & 11.84 & 8.25 \\
\hline 2006 & 117.5 & 4623.1 & 13.35 & 392.14 & 11.36 & 8.48 \\
\hline 2007 & 132.7 & 5265.6 & 17.53 & 5.6 .47 & 13.21 & 9.61 \\
\hline 2008 & 141.1 & 5629.2 & 20.40 & 626.18 & 14.45 & 11.12 \\
\hline
\end{tabular}

Source: Department of Tourism, Government of Tamil Nadu

There are 24 tourist offices (18 within the state of Tamil Nadu and 6 are in outside the state) operated by Tamil Nadu Tourism Development Corporation, (TTDC), Chennai. There are 5 world heritage monuments, 85 monuments maintained by the State Archaeology Department, 247 monuments maintained by the Archaeological Survey of India (ASI). There are 11 forts, 41 museums, 38436 temples, 5 major ports, 3 hill stations, largest beach (13 Kms), highest peak Doddabetta (2636 mtrs), 3 telescope houses and 23 amusement parks. It encompasses a wide spectrum of tourism products. It is noted that rural tourism along with festival tourism has boosted the image of Tamil Nadu, a violence free economy along with peace loving people, attracted the domestic and foreign tourists. The Tourism report has stated that the length of stay of an average tourist in Tamil Nadu is four to five days in the case of a domestic tourist and seven days in case of a foreign tourist (GOT, Policy Note 2010). A foreign tourist spends Rs. 4396/- a day and a domestic tourist spends Rs. 1422/- a day and a day visitor spends Rs $540 /$ - a day. Table 1 is self-explanatory in nature, and it shows that Tamil Nadu occupies an important place in the tourism map of India. Each district in Tamil Nadu has great tourism potential and the tourism popularity of these districts are presented in the Table 2 and Fig. 1 
Table 2: Tourism Potential and Popularity of Districts in Tamil Nadu

\begin{tabular}{|c|c|c|}
\hline Sl. No. & District & Nick/ Groove Name \\
\hline 1. & Chennai & The Capital city of Tamil Nadu \\
\hline 2. & Ariyalur & Land of Limestone \\
\hline 3. & Coimbatore & The Manchester of South India \\
\hline 4. & Cuddalore & The cosmic dancer's place \\
\hline 5. & Dharmapuri & Land of horticulture and forest wealth \\
\hline 6. & Dindigul & The Lock and Tannery City \\
\hline 7. & Erode & Important Market centre for Turmeric \\
\hline 8. & Kanchipuram & The city of Thousand Temples, \\
\hline 9. & Kanyakumari & South tip of India, \\
\hline 10. & Karur & Rich and varied cultural heritage, \\
\hline 11. & Krishnagiri & Land of Mangoes \\
\hline 12. & Madurai & The Athens of East \\
\hline 13. & Nagapattinam & The land of religious harmony \\
\hline 14. & Namakkal & The Poultry city of Tamil Nadu \\
\hline 15. & Nilgris & Queen of Hill stations \\
\hline 16. & Perambalur & Inland district of Tamil Nadu \\
\hline 17. & Pudukkottai & The Princely City \\
\hline 18. & Ramanathapuram & The Holy Land \\
\hline 19. & Salem & A Geologist's Paradise \\
\hline 20. & Sivagangi & The Land with a Hoary Past \\
\hline 21. & Thanjavur & The Rice bowl of Tamil Nadu \\
\hline 22. & Theni & District of Natural Lovers \\
\hline 23. & Thoothukudi & The Pearl Paradise \\
\hline 24. & Tiruchirappalli & The Rock city \\
\hline 25. & Tirunelveli & The Pride of Tamils \\
\hline 26. & Tirupur & Knitwear Capital \\
\hline 27. & Tiruvallur & The City of fast Developing \\
\hline 28. & Thiruvannamalai & The most sacred shrines of Tamil Nadu \\
\hline 29. & Thiruvarur & The Birth place of Carnatic Musicians \\
\hline 30. & Vellore & The Fort City \\
\hline 31. & Villupuram & Early war land of South \\
\hline 32. & Virudhunagar & The Emblem of State \\
\hline
\end{tabular}

Source : Compiled from various pamphlets 


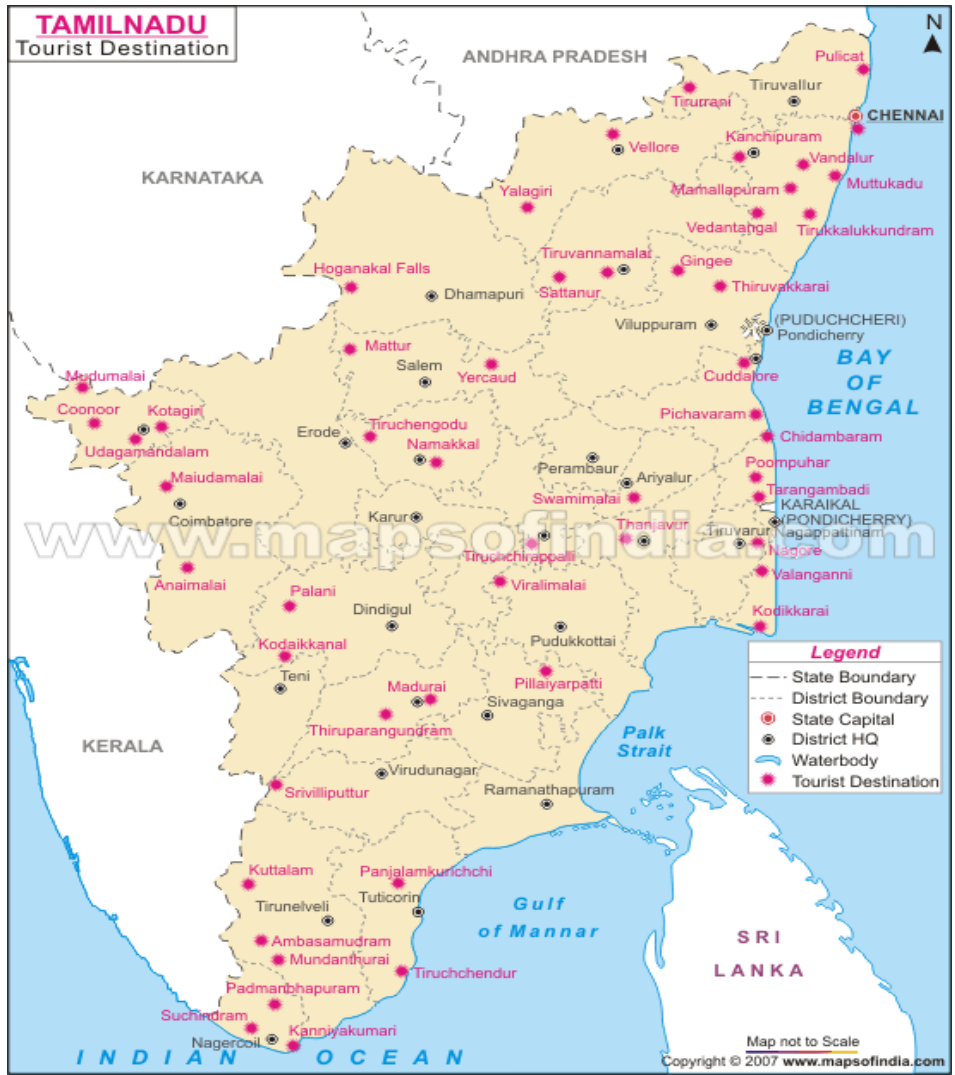

Fig. 1: Districts of Tamil Nadu: Groove Name

Tamil Nadu: Treasure of Shrines and Multi-Faceted Institution; Source: www.mapsofindia.com

pilgrimage has been defined as, a journey resulting from religious causes, externally to a holy site, and internally for spiritual purposes and internal understanding (Barber, 1993), Pilgrimage tourism not only builds our religious faith, but also strengthens our national unity and promotes brotherhood (Arnab Karar 2010). India is a land of temples, churches and mosques. Temples in India in general and Tamil Nadu in particular have a rich cultural heritage of their own. The south Indian temples played a multifaceted role in the religious, social and economic life of the people. The temple is considered as a place of worship, as well as a centre for religious and cultural activities. Tourists' potential of a country or a place mainly depends on its climate, scenery, historical monuments, arts, traditional festivals and the people. Palani, the area for the present work, is not only a regional tourist and pilgrim 
spot, but also serves as the same for the national tourists. The number of North and South Indians visiting Palani has been continuously increasing. Historical evidences show that many cities and towns have developed mainly based on temples, churches and mosques. The entire economic activities of the religious based towns and cities, are dependent upon temples; for instance, Kashi, Thirupathi, Rameswaram and Palani. These are the places that have developed as big towns and cities and helped for the economic and other productive activities of the people around the temple complex, due to the visits made by the domestic and foreign tourists.

Temple as a Producer: As a land lord, temple helps the production of paddy and other crops too. It produces 'Sacred ash' and rose water. The temples provide services, which satisfy the needs of the devotees and these services may be divided into spiritual services and material services like performing poojas on the temple and conducting 'Yagas', of which festivals may be considered as spiritual services. The provisions of convenience extended to the devotees are an example of the material service rendered by the temple.

Temple as Consumer of Goods: The religious centres are associated with many artisans and traders, who are involved in building coaches and chariots and creating towers for the temples. They generally stay nearer to the temple premises. Many industries such as those connected with melting and casting and working in gold and silver run, to meet the requirements of the temple. The donors make constant offerings of jewellery for their favourite deities and, it naturally encourages the sculptures and other artisans whose products are regularly bought by the temple. Secondly, the pilgrims coming to pay homage at the temple, generally return to their home with small images of the deities, cast in metal or stone and keep it in the pooja room for worship. The flow of pilgrims at festive time gives employment opportunities to the guide priests, inn-keepers, food sellers etc., Moreover, temples encourage local trade, industries and markets.

Temple as Land Owner: In the olden days, land was considered as the only permanent source of income for the temple. There are many occasions in the case of South Indian temples, when the kings 
liberally donated lands; besides the kings' local rulers, officers, merchants etc. have donated lands or endowed money with the village administrative authority. It may be pointed out here that the temples in Tamil Nadu own land with two aims. The first aim is to get paddy required for pooja purposes. The other aim is to get income by leasing out the land and utilizing it for the development of the temple; since lands are situated far away from the temple, the temple becomes an absentee landlord.

Temple as Employer: The Hindu temple is unlike the Christian church or Muslim mosque, which provides employment on a permanent basis for few persons. The temple has always provided employment for several categories of people. The functionaries of the temple may be classified under four heads: those providing spiritual services like conducting the various activities of worship, chanting mantras, reciting hymns and singing songs to the deity; those carrying out the administration pertaining to the temple, manage temple and temple affairs, supervise the staff and maintain the accounts of the temple; those rendering various kinds of manual labour in connection with the temple, such as keeping the temple environment clean and washing the vessels, and artists, such as musicians skilled in playing the typical instruments connected with temple worship, making beautiful garlands and drawing attractive patterns on the floor by making designs, decorations, shapes etc for the purpose of beautification and adornments.

Temple as Trustee: The Temple plays an important economic role as a trustee for the wealth and income given by the people, which may be used for the welfare of the people. When rich people wish to spend a portion of their income for the cause of 'dharma' or righteousness, the temple provides a suitable avenue whether the amount is large or small. Both the poor and rich make their able contribution to the temple considering it to be a trustee of public welfare.

Temple as Redistributors of Income: The Temple plays a role as the redistributors of income. People give a portion of their disposable income in the form of offerings to the temple. The temple spends these offerings in various ways, enabling the 
redistribution of the income. How the temple plays a role in the circular flow of income may best be explained in Fig 2.

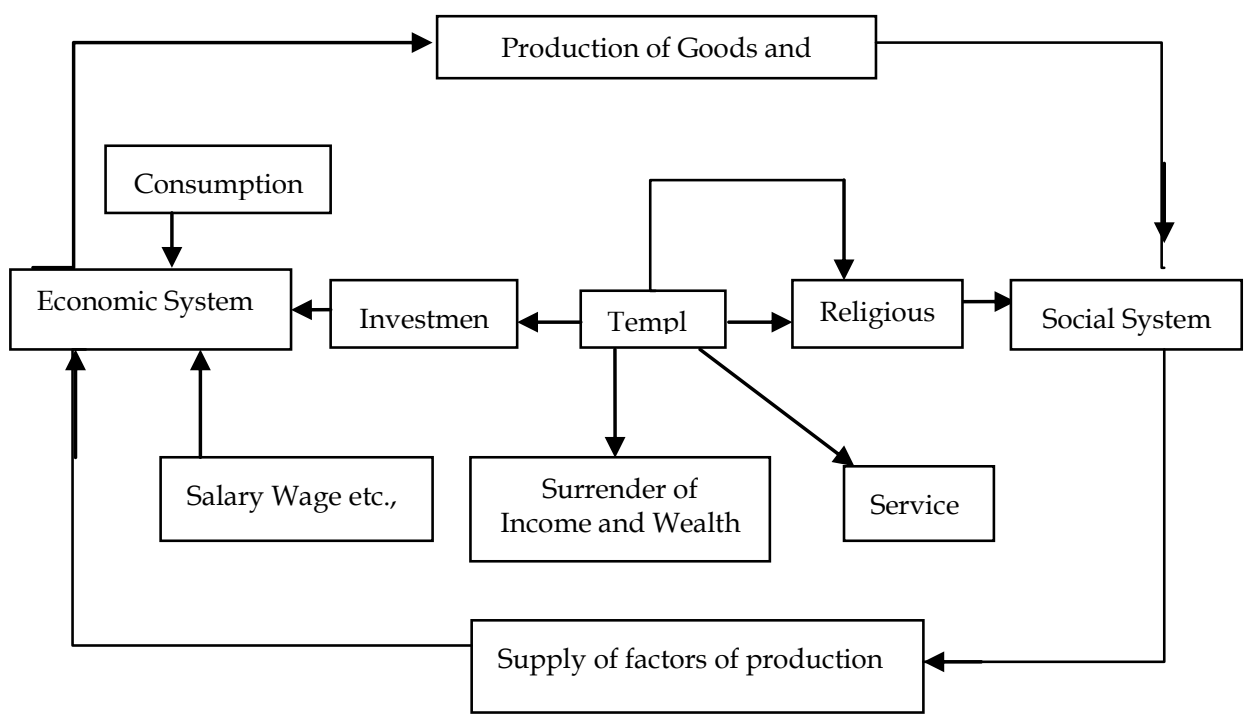

Fig. :2 Temple- Circular Flow of Income

Source: Malarvizhi and Ramaswamy (1996)

Temple as Pilgrim and Tourist Centre: Tourism has been defined as the sum of the relations and services connected with temporary and voluntary changes of residence for non-commercial or nonprofessional reasons. Tourism plays an important role in the economic development of the country. The impact of tourism on national economy is becoming increasingly important because of (i) the growing size of the tourist market; (ii) big industry and big booster of modern economy; (iii) virtually a gold mine; (iv) potential earners of foreign exchange; (vi) promote cultural relations and international co-operations; (vii) Source of employment because it is a highly labour oriented industry; and (viii) provides quick relief to unemployment. Temples in India possess these characteristic features of enjoying the merits and the advantages of tourism, which are spectacular in nature.

Temple as an Institution: The Temple is one of the basic institutions of Hinduism. It is one of the ancient and charitable economic units. The Endowments Act of 1959 defines: "temple as a place used for public, religious worship and dedicated to the 
Hindu community or any functions thereof as a place of public religious worship. Temple is not only a place of worship but also serves as a social and - economic institution. The Temple owns properties in the form of buildings, land and ornaments and receives income in various forms like cash and kind. Moreover, it has the freedom to collect some fees inside the temple. Further, it undertakes many cultural activities in addition to its regular rituals prayers and festivals and hence its existence is more important from the point of view the society.

Temple as Religious and Cultural Institution: Religion gives a set of meanings and values and a sense of purpose in life. The Temple is considered as a religious and cultural institution, because it is used for common worship and thus all sections of the society rich or poor, haves and have nots, marginal and disadvantaged come here and worship the gods and goddess.

Temple as Social Institution: Temples are a social institution managed by a group of people or by a particular caste/ community or religion or trust. But, at present the government or quasi government is either directly or indirectly involved in the administration and management of temples. In fact, the Hindu Religious Endowment Board is responsible for managing and administering the temples in Tamil Nadu.

Temple as an Economic Institution: The Temple seems to be an economic institution, because it helps in employment generation and thus creates income from the properties and land owned by it. As far as the study on the Palani temple is concerned, it attracts tourists and pilgrims from various parts of the country and generates employment opportunities to the various sections of the society such as different service providers (taxi operators, autorickshaw owners, hotel owners, lodge owners and other commercial establishments). Based on the above background, the researcher wishes to review and study the Reminiscence of Pilgrimage Tourists: A Case of Palani Temple, Tamil Nadu

\section{The Objectives}

- To examine the socio and economic characteristics of cultural and spiritual tourists visiting Palani; and 
- To identify the major problems faced by the cultural and spiritual tourists and suggest ways and means for promoting pilgrimage tourism in Palani.

\section{The Methodology}

This study is descriptive in nature, mainly based upon primary and secondary data. The primary data have been collected through interview schedules. The interview schedule was pre-tested and after the pre-test, a modified and well-structured interview schedule was administered for obtaining information and data from the cultural-spiritual tourists who are visiting the Palani temple. Secondary data in connection with the Palani temple were also gathered from the Office of the Commissioner, Palani temple. Further, the authors have collected data and information from 150 tourists, who visited the Palani temple during June-July 2011. The tourists were purposively selected in different spots in and around the Palani temple. For the purpose of analyzing the data, simple tools like ratio, percentage and average were used.

\section{Profile of the Study Area}

Palani is the Taluk headquarters, and is one among the seven Taluks of the Dindigul district of Tamil Nadu. The Palani Taluk lies in the Northwest corner of Dindigul. The Palani town is gaining more and more importance due to its location on the top of the hill. The Palani hill, the third sacred abode of Lord Muruga, rises to a height of $137.16 \mathrm{M}$ and $1068 \mathrm{Ft}$, (or) 324M above the sea level. Palani has three blends of climates from Rainy season (September to November), winter season (December to March), and summer season (April to June). Palani is a well developed municipal town. The railway station is situated on the northern side of Palani town; it was started in the year 1929. By road, Palani can be conveniently reached from important towns in Tamil Nadu and Kerala. The major festivals in Palani are Panguni Uthiram, Thai Poosam, Kandhashashti, Vaikasi Visakam, Agni Nakshatrm and other festivals like Thirukarthigai, Thai Amavasai, Tamil New Year, $18^{\text {th }}$ day of Aadi month and Tamil month of Margazhi. A nominal fare is charged by the temple authorities for the winch to carry the tourists to reach the top of the hill. 


\section{Major Findings of the Study}

Out of 150 pilgrimage tourists, 88.0 per cent are in the age group ranging between 15-59 years, and majority of them (63.0 per cent) are female; 98.5 per cent are Hindu; 95.0 per cent are coming from Tamil Nadu and the rest are from Kerala (5.0 per cent) ; the visitors come from various districts like Coimbatore, Dindigul, Erode, Madurai, Salam, Karur, and Trichy; 68.0 per cent of them are from town areas and metropolitan cities; majority of them (65.0 per cent) are dependent. Most of them (34.0 per cent) completed high school, 28.0 per cent studied up to college level, 13.0 per cent studied higher secondary and primary school and rest of them are illiterate (25.0 per cent); 28.0 per cent of them are business men followed by labourers (22.0 percent), agriculturists (29.0 per cent) and workers (21.0 per cent); the average per capita income of the tourist is Rs 26,202/- and the average distance travelled by the tourists is 157 $\mathrm{km} ; 79.0$ per cent preferred the bus to reach Palani, and 21.0 by car; 22.0 per cent stayed at hotels, chatthiram and madam (choultry) in Palani; majority of them (78.0 per cent) did not stay at Palani, 69.0 per cent visited Palani more than 5 times and 13.0 per cent visited 5 to 10 times; 15.0 per cent visited 10 to 15 times and 3.0 per cent visited more than 15 times, and Per capita expenditure of tourist is Rs 2521.44.

\section{Opinions of Pilgrimage Tourists}

Of the 150 pilgrimage tourists, 79.0 per cent of tourists arrived at Palani by bus and the rest preferred car (21.0 per cent), of which 9.0 per cent are dissatisfied with bus transport, 18.0 per cent are satisfied with car transport and most of the visitors opined that train service should be restarted and conversion to broad-gauge should be completed rapidly; majority of the tourists sensed (80.0 per cent) that the toilet facility is good and rest of them said that it is bad; 75.0 per cent conveyed that drinking water facility is good; 67.0 Per cent stated that health care and medical facilities are good; 93.0 per cent reported that local transport facility is good; 90.0 per cent opined that the quality of prasadham, a holy food is good; 83.0 per cent informed that the environmental surroundings of the temple is good; 87.0 per cent described that the temple administration is good; 71.0 per cent stated the quality of food is 
also good and they reported that the entrance fee seems to be low; 85.0 per cent felt that the winch facility is good but most of the visitors preffered to walk to reach the top of the hill; majority of the visitors (67.0 per cent) preffered free dharsan, rather than paid dharsan; 37.0 per cent felt that they faced problem with the priests, followed by tourists guides, shop owners and the taxi drivers.

\section{Problems Faced by the Pilgrimage Tourists}

A Pilgrimage Tourism spot like Palani, must be disseminated with a host of information, which should reach both the domestic and the foreign tourists. Infrastructure facilities like good hotels, eco lodges, affordable and hygienic accommodation, and drinking water are lacking and thus they must be improved. Some of the problems identified by pilgrimage tourists are: unhygienic food, lack of drinking water supply, poor sanitation coupled with poor drainage facility, scanty accommodation, poor co-ordination between temple authorities and the pilgrimage tourists, exorbitant prices of food, pooja items, prasadham, horse cart, winch, paid dharsan, taxi fare etc., Moreover, unregistered guides are exploiting the pilgrimage tourists in terms of wrong and poor guidance. Insufficient transport facilities, especially, special buses during peak festival times add to these problems; the suspension of train service caused by broad gauge conversion is yet another transport problem faced by the tourists. The net result is exorbitant prices charged by alternative transports like autos taxies and horse carts. Majority of the pilgrimage tourists' felt that Palani temple and its environment seems to be very poor due to over- crowding and continuous flow of mass tourists, particularly during festive times.

\section{Strategies for Future Development}

Tourists, both domestic and foreign, visit different places in search of specialities, which include a variety of things, such as, beauty of nature, architecture, peace of mind and fulfilment in religious places, new and different varieties of food, culture of the people and uncommon adventures. In the midst of so many varieties, tourists make certain common demands, and they are: (i) clean, hygienic and comfortable living accommodation; (ii) good transport system to take them from one place to another; (iii) decent shops, particularly catering to ethnic art, clothes and (iv) 
entertainment representing cultural heritage of the place. Tourists invariably seek a pleasant and delectable experience on their trips. it consists of (a) an environment of peace and stability, (b) an assurance of safety and security, (c) an affable host society, (d) tourism industry and the governments (State and Local) that provide the requisite pilgrimage tourism service with a smile, (e) absence of extortion and hostility, and (f) accessible tourist attraction are the need of the hour to sustain pilgrimage tourism. Moreover the slogan of Athithi Devo Bhava (Treat the Guest as God) has to be practiced. The services of hospitality have to be improved during festival and other times.

\section{Conclusion}

Tourism has emerged as an instrument for employment generation, poverty alleviation and sustainable human development. In recognition of this aspect, the government has taken earnest efforts to improve infrastructure at various tourist destinations, including the pilgrimage centres like Palani. In order to ensure sustainability of pilgrimage tourism, proper upkeep, operation and maintenance would be made as part of the tourist projects in future. Tourism can thrive and prosper only when, there is peace and tranquillity. The issues concerning safety and security of pilgrimage tourists and their belongings should be kept in mind. Effective co-ordination among various organizations including tourist agencies and sectors like transport should be ensured for promotion of pilgrimage tourism.

\section{References}

Barber, R. (1993). Pilgrimages. London: The Boy Dell Press.

Government of Tamil Nadu (2010). Policy Note 2009-10. Tourism and Culture Department. Chennai.

Karar, A. (2010). Impact of pilgrim tourism at Haridwar. Anthropologist, 12(2), 99-105.

Malarvizhi, C. A., \& Ramaswamy, S. (1996). Planning for rural tourism: A study with special reference to Thirumakaikeni. Unpublished M.Phil Dissertation to Gandhigram Rural Institute-Deemed University, Gandhigram. 